\title{
In Focus
}

Spotlight on the July 27 Issue

Robert A. Gross, MD, PhD, FAAN

Editor-in-Chief, Neurology ${ }^{\circledR}$

\section{Familial neuromyelitis optica}

This paper describes a case series involving the demographic, clinical, neuroimaging, and NMO-lgG serologic status of 12 multiplex neuromyelitis optica (NMO) pedigrees in a total of 25 affected individuals. Familial NMO was indistinguishable from sporadic NMO based on clinical symptoms, age at onset, sex distribution, and frequency of NMO-lgG detection, suggesting complex genetic susceptibility in NMO. See p. 310

\section{Redefining dysferlinopathy phenotypes based on clinical} findings and muscle imaging studies

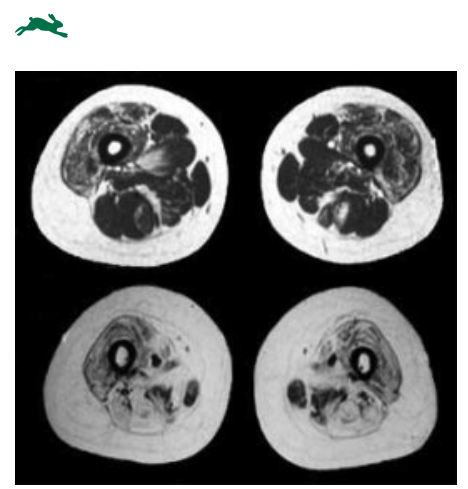

This retrospective study assessed lower limb MRI in 29 patients to identify the pattern of muscle impairment and quantify involvement. The finding that proximal and distal muscles were already impaired at onset in both Miyoshi myopathy and limb-girdle muscular

dystrophy $2 \mathrm{~B}$ favors grouping all phenotypes under the term dysferlin myopathy.

See p. 316; Editorial, p. 298

Quality of life declines after first ischemic stroke:

The Northern Manhattan Study

in 매

The long-term quality of life of stroke patients is not well characterized. In this population-based study of 525 patients with first ischemic stroke, there was a linear decline in quality of life over 5 years independent of recurrent vascular events and common predictors.

See p. 328
AMERICAN ACADEMY OF NEUROLOGY
Use of antiepileptic drugs in epilepsy and the risk of selfharm or suicidal behavior

[1] 陆

This observational study investigated the risk of suicidal behavior associated with the use of antiepileptic drugs in 44,300 patients with epilepsy. The authors found an increased risk in some of the newer antiepileptic drugs, but not from the most commonly used antiepileptic drugs.

See p. 335; Editorial, p. 300

\section{Physical activities and future risk of Parkinson disease}

Physical activity was evaluated in 213,701 participants in the NIH-AARP Diet and Health. The authors found that higher levels of moderate to vigorous physical activities were associated with lower risk of Parkinson disease; further analysis suggests that this finding might not be due to reverse causality.

See p. 341

Cortical neuroanatomic correlates of symptom severity in primary progressive aphasia

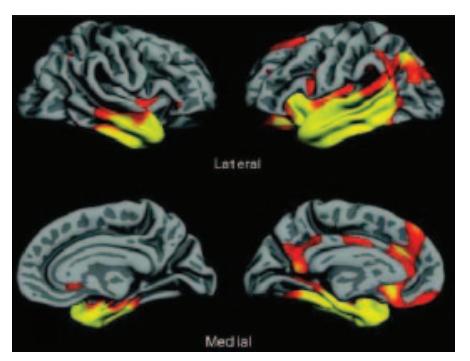

Forty right-handed patients with primary progressive aphasia had performancebased language testing using the Progressive Aphasia Severity Scale (PASS) and MRI scans. These data support the value of PASS and MRI as novel clinical measures and as markers for potential use in clinical research and trials in primary progressive aphasia. See p. 358

Nongenetic factors influence severity of episodic ataxia type 1 in monozygotic twins

回质

The authors evaluated 3 families with episodic ataxia type 1 phenotype, 2 of which included monozygotic twins. They sequenced the KCNA1 gene and studied the biophysical consequences of the mutations in HEK cells. The occurrence of epilepsy in 1 of 2 families with the F414S mutation suggests interplay of KCNA1 with other genetic factors.

See p. 367

Podcasts can be accessed at www.neurology.org 


\title{
Neurology
}

\author{
In Focus: Spotlight on the July 27 Issue \\ Robert A. Gross \\ Neurology 2010;75;295 \\ DOI 10.1212/WNL.0b013e3181ea166b
}

This information is current as of July 26, 2010

\section{Updated Information \& Services}

Permissions \& Licensing

Reprints including high resolution figures, can be found at: http://n.neurology.org/content/75/4/295.full

Information about reproducing this article in parts (figures,tables) or in its entirety can be found online at:

http://www.neurology.org/about/about_the_journal\#permissions

Information about ordering reprints can be found online:

http://n.neurology.org/subscribers/advertise

Neurology ${ }^{\circledR}$ is the official journal of the American Academy of Neurology. Published continuously since 1951, it is now a weekly with 48 issues per year. Copyright. All rights reserved. Print ISSN: 0028-3878. Online ISSN: 1526-632X.

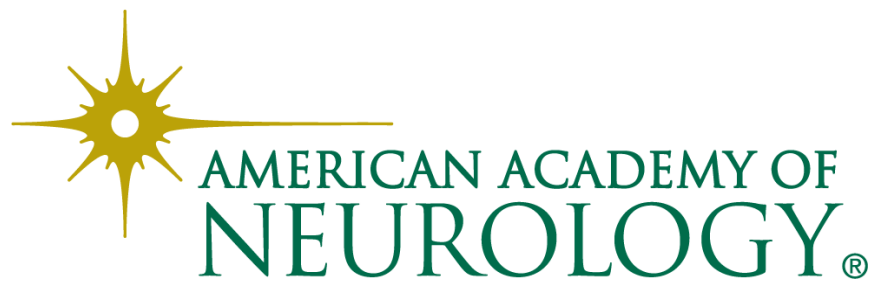

